\title{
The Influence of Human Resources are Moderated with Mentoring and Training Against the Readiness the Implementation in Government Regulation Number 12 Of 2019
}

\author{
Adjie Avinda ${ }^{1}$, Afridian Wirahadi Ahmad ${ }^{2}$, Rasyidah Mustika ${ }^{3}$, Elfitri Santi ${ }^{4}$ \\ \{adjiejiee25@gmail.com ${ }^{1}$, afridianpadang@gmail.com², titik.mustika@gmail.com³ \\ elfitrisanti.pnp@gmail.com ${ }^{4}$ \} \\ Politeknik Negeri Padang, Padang, Indonesia
}

\begin{abstract}
This research is motivated by changes to the regulations on regional financial management, namely Government Regulation Number 12 of 2019. Changes to this regulation become the main benchmarks in the development of financial growth in the city government of Padang. The purpose of this research is to determine the factors that influence the readiness of the government in dealing with the application of Government Regulation Number 12 of 2019. The research method used is a quantitative method using a questionnaire. The population of the research is the Regional Device Organization (RDO) in the Padang City with random sampling and 161 respondents. This research used Moderated Regression Analysist (MRA). The results of this research indicate that human resources have a positive influence on the readiness of the government in dealing with changes that are moderated by mentoring and training. Other indicate that human resources have a positive influence on preparation of application of Government Regulation Number 12 of 2019. This shows the limitations of research in sampling and the addition of research variables.
\end{abstract}

Keywords: The Influence of Human Resources, Mentoring and Training

\section{Introduction}

The development of financial management reforms in Indonesia is still ongoing. This is intended so that the mandate contained in article 3 paragraph 1 on Ordinance Number 17 of 2003 concerning State finance, which requires that State finance be managed in an orderly manner, abiding by the laws and regulations, efficient, effective, economical, transparent and responsible by paying attention to a sense of justice and obedience, can be increasingly realized.The main mission of the Act produces an indicator that financial management activities both at the central and regional levels have full responsibility in regulating good governance, especially in regulating State finance.

Local governments continue to make improvements in financial management, one of which is to get an qualified opinion although with Governement Regulation Number 12 of 2019 is Padang City. According to [1] states get unqualified opinion because all financial statements have met the appropriate accounting standards and meet national and international standards. This makes Kota Padang can maintain its unqualified opinion with readiness to apply Government Regulation Number 12 of 2019 and also become the regional government that has the highest rate of economic growth during the 2016-2018 period so Kota Padang must 
maintain some of its achievements as a benchmark in readiness to face Government Regulation Number 12 of 2019.

Research from [2] indicates that the factors that influence the readiness of the government in applying accounting standards in local governments are human resources that are moderated by mentoring and training, organizational commitment and means of targeting in the local government. This shows the relationship between human resources with assistance and training that will be applied by local governments.

The purpose of this research is to answer the problems in this study. This study aims to determine the effect of human resources moderated by assistance to the readiness of the Padang City Government in dealing with Government Regulation Number 12 of 2019 and to determine the effect of human resources moderated by training on the readiness of the Government of Padang City in dealing with Government Regulation Number 12 of 2019 Contribution in research is for science and the City Government of Padang. For science, it contributes to providing academic studies on the readiness of the Padang City government in facing and implementing Government Regulation Number 12 of 2019 and as a reference, information and additional literature for readers interested in the study of regional financial management. And for the Government of the City of Padang, it can be used as a material for consideration in making decisions of the Government of the City of Padang in regulating regulations regarding regional financial management, such as Government Regulation Number 58 of 2005 which is replaced with Government Regulation Number 12 of 2019. This research is expected to be used to carry out management activities Regional finance is more productive and beneficial for stakeholders.

\section{Methodology}

This research uses the type of research in the form of empirical studies, according to [3] empirical study is to mean the methods carried out are observed by the human senses, so that others can observe and know the methods used while the approach used is a quantitative descriptive approach. This research is sourced from primary data and secondary data. Primary data is data that comes directly from data sources specifically collected that are directly related to the problem under study. This data was obtained from a research questionnaire. The questionnaire is a list of questions distributed by post to be filled out and returned. The questionnaire used was a questionnaire from [2] as well as a questionnaire from [4]. Questionnaires were given to the Padang City Regional Organization (OPD) which was used to gather information for data processing research. While secondary data is data that is not obtained directly by researchers but is obtained from reports, books, research journals, scientific papers, articles, scientific magazines related to research problems [5].

Population is a generalization area consisting of objects / subjects that have certain characteristics and qualities determined by researchers to be studied and then drawn conclusions [3]. The population of this study is the Padang City Government which consists of 52 OPD units. The 52 units of OPD are divided into Agencies, Offices, Offices, Sections, Districts and Others.

The sample used in this study is simple random sampling. [6] states that simple random sampling is random sampling where each population has the opportunity to be sampled. Determination of the sample made by researchers using the Slovin formula. [7] states that the Slovin formula is indicated to determine the minimum sample in a study. Use this formula on 
the basis of random sampling without regard to any sample on the basis of too many populations. The Slovin formula is as follows:

Information:

$$
n=\frac{N}{1+N e^{2}}
$$

$\mathrm{N}$ : Number of samples

$\mathrm{N}$ : Total population

$\mathrm{e}^{2}$ : Percentage of allowance for research due to sample errors that can still be tolerated $(0.05)$

Data analysist performed was a Moderated Regression Analyst (MRA) and multiple regression with the help of calculations through the SPSS program. MRA is used to determine the effect of interactions between the mentoring variables (Z1) and training (Z1) with the human resource variable $(\mathrm{X} 1)$ on the readiness of local government variables in dealing with Government Regulation Number 12 of 2019. Analysis of the regression analysis is to determine whether there is a significant influence between one or more independent variables (human resources, organizational commitment, infrastructure, and legal aspects) to the dependent variable partially or simultaneously [8]. The use of the MRA model is to compare three regression models and see beta (b) between regressions. Following are the terms of the use of MRA [9]:

1) $\mathrm{b} 2=0$ and $\mathrm{b} 3 \neq 0$. Pure moderator

2) $\mathrm{b} 2 \neq 0$ and $\mathrm{b} 3 \neq 0$. Pseudo moderation (Quasi Moderator). Quasi Moderator is a variable that moderates the relationship between the independent variable and the dependent variable which also becomes an independent variable

3) $\mathrm{b} 2 \neq 0$ and $\mathrm{b} 3=0$. Predictor Moderator (Predictor Moderator Variable) means that this moderating variable only acts as a predictor variable (independent) in the relationship model formed

4) $\mathrm{b} 2=0$ and $\mathrm{b} 3=0$. Potential moderation (Homologiser Moderator) means that the potential variable becomes a moderating variable

The following equations can be formed from the MRA model:

$\mathrm{Y} 1=\mathrm{a}+\mathrm{b} 1 \mathrm{X} 1+\mathrm{e}$

$\mathrm{Y} 1=\mathrm{a}+\mathrm{b} 1 \mathrm{X} 1+\mathrm{b} 2 \mathrm{Z} 1+\mathrm{e}$

$\mathrm{Y} 1=\mathrm{a}+\mathrm{b} 1 \mathrm{X} 1+\mathrm{b} 2 \mathrm{Z} 1+\mathrm{b} 3 \mathrm{X} 1 * \mathrm{Z} 1+\mathrm{e}$

(equation 2)

$\mathrm{Y} 1=\mathrm{a}+\mathrm{b} 1 \mathrm{X} 1+\mathrm{e}$

$\mathrm{Y} 1=\mathrm{a}+\mathrm{b} 1 \mathrm{X} 1+\mathrm{b} 4 \mathrm{Z} 2+\mathrm{e}$

$\mathrm{Y} 1=\mathrm{a}+\mathrm{b} 1 \mathrm{X} 1+\mathrm{b} 4 \mathrm{Z} 2+\mathrm{b} 5 \mathrm{X} 1 * \mathrm{Z} 2+\mathrm{e}$

Information :

Y1 : Dependent variable

A : The value of the price constant $\mathrm{Y}$ if $\mathrm{X}=0$

B : The value of the direction as a prediction (prediction) which shows the value of increasing $(+)$ or decreasing value (-) of variable $\mathrm{Y}$

$\mathrm{X} 1 \quad$ : Independent variable (human resources)

$\mathrm{Z1}, \mathrm{Z2}$ : Variable moderation (training and mentoring)

E : Error 


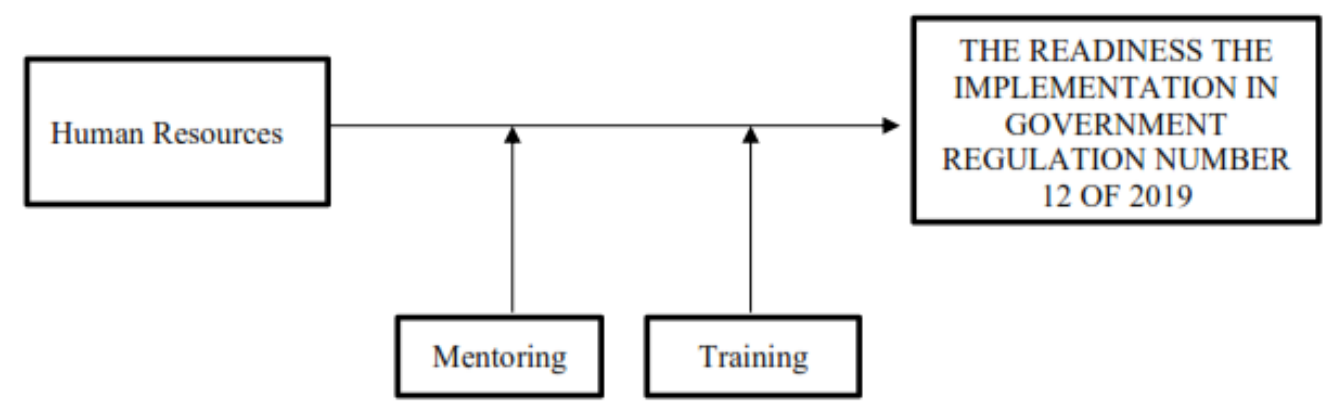

Fig. 1. Research Model

\section{Result and Discussion}

\section{Result}

The results of regression testing with the readiness of the government in dealing with Government Regulation Number 12 of 2019 as the dependent variable, human resources as an independent variable and assistance as a moderating variable indicate the tcount of human resources (X1) is equal to 3,943 with a significance of $t$ value of 0,000 (significant). Assistance variable (Z1) shows that tcount is 2.872 with a significance of $t$ value 0.005 (significant). These results also prove by comparing beta (b) in MRA. The comparison results that both $\mathrm{b} \neq 0$, it can be concluded that the mentoring variable is a quasi moderation variable. Quasi moderation variable is a moderation variable that can be used as an independent variable in this study. This shows that the better the interaction of assistance in improving the quality of human resources, the better the readiness of the government in dealing with Government Regulation Number 12 of 2019. Thus, the first hypothesis is accepted.

Test results on the IB regression model showed similarity in calculations, but differed in the moderating variable. This test uses a training moderation variable that shows the tcount of human resources (X1) is 2.925 with a significance of $t$ value of 0.004 (significant). The training variable (Z2) shows that count is 4.317 with a significance of $t$ value of 0.000 (significant). These results also prove by comparing beta (b) in MRA. The comparison results that both $\mathrm{b} \neq$ 0 , it can be concluded that the training variable is a quasi moderation variable. Quasi moderation variable is a moderation variable that can be used as an independent variable in this study. This shows that the better the interaction of training in improving the quality of human resources, the better the readiness of the government in dealing with Government Regulation Number 12 of 2019. Thus, the second hypothesis is accepted. The results of the regression analysis showed the tcount of human resources (X1) was 1,828 with a significance $t$ value of 0.069 (no significance). The results show that human resources do not significantly influence (X1) the government's readiness to face Government Regulation No. 12 of 2019. This shows that more or less human resources carry out regional financial management, so there is no effect on the readiness of local governments in facing readiness the application of Government Regulation Number 12 of 2019. Thus, the third hypothesis was rejected.

\section{Discussion}

Mentoring as a strategy that is commonly used by governments and non-profit organizations in an effort to improve the quality and quality of human resources, so as to identify themselves as part of the problems experienced and strive to find alternative solutions to the 
problems encountered. Increasing human resources can be done with assistance by other human resources because humans are created as social creatures who really need other human beings in carrying out their activities so that they can improve the quality of human beings themselves. This shows that assistance is related to how the quality of human resources in facing the readiness to carry out activities to be planned.

The results of testing the hypothesis in this study indicate that there is a positive interaction between mentoring and human resources on the readiness of local governments to face Government Regulation Number 12 of 2019 significantly. The more often assistance is provided to employees, the more skills and knowledge they can carry out in doing work and the easier it is to solve problems. This finding is in line with the concept expressed by [10] which says that with the assistance of the government apparatus there will be a process of creative change initiated by the apparatus themselves. This assistance is also a benchmark in the application of the theory of the New Public Management (NPM). [11] shows that NPM emphasizes changes in government behavior that is more effective and efficient in carrying out its activities, one of which is by providing assistance. This is in line with [2] which states that there is a positive influence between mentoring and human resources on readiness in applying accrual-based accounting.

Training must provide a mechanism for employees to understand, accept and feel comfortable with ideas and instruments in implementing NPM that will be applied by local governments. Training is part of the education process in every human resource. Human resources become the main benchmark in carrying out regional financial management in the Regional Government Organization (OPD) so that training needs to be done as an organizational investment in order to increase understanding of preparedness in facing Government Regulation Number 12 of 2019. This shows that the training provided to sources human power will increase their skills, knowledge and understanding of the work they do.

The results of hypothesis testing indicate that there is a positive influence of interaction between training and human resources on the government's readiness in facing Government Regulation

Number 12 of 2019 significantly. Human resources have a central role in determining success in preparing an activity to be carried out. These findings indicate that the quality of human resources in the Padang Municipality Regional Government participating in the training is ready in preparing themselves for change. This shows that this research is in line with [2].

Human resources are the most supportive indicator tool in the optimization of the task field, particularly in the management of regional finances. The implementation of financial management activities requires high integrity for human resources to encourage their activities. Carrying out all these activities also requires a willingness to work hard and be disciplined, have loyalty, have the ability in the field of accounting, and the placement of human resources in accordance with their educational background. This will show that human resources will be more effective and efficient in conducting financial management when changes in rules occur.

The influence that occurs on human resources in the Padang City Government is indicated that there is no influence on the readiness to face the expectations of Government Regulation Number 12 of 2019. This finding is also explained in [2] which states that the quality of human resources does not affect the readiness to face accounting standards accrual basis. However, this finding was opposed by research from [12], [13] and [4] which stated that the quality of human resources had a positive effect on changes in the accrual-based accounting 
system. This difference becomes a benchmark to assess the human resources in the City Government of Padang. Many human resources are placed not in accordance with the educational background they have so that the level of understanding possessed by human resources is still lacking when preparing to face Government Regulation Number 12 of 2019. Thus, the government must conduct training and assistance as aspects that support in improving the quality of human resources and selective in placing human resources in accordance with their educational background.

\section{Conclusion}

Based on the results of this study, the following conclusions can be concluded:

1) Regional financial management has experienced a change in the rules that are applied in every region in Indonesia, namely the Government Regulation Number 12 of 2019.

2) Changes that occur in financial management need the readiness of the government in dealing with the changes that will be applied, especially in the Padang City Government which is the main benchmark in managing regional finances.

3) Readiness in the face of the application of Government Regulation Number 12 of 2019, the Government of Padang City must prepare financial management activities with the following results:

a. There is a positive interaction between assistance and human resources on the readiness of the Padang City Government in facing the issuance of Government Regulation Number 12 of 2019 so that human resource assistance needs to be done as a step in the implementation.

b. There is a positive interaction between training and human resources on the readiness of the Padang City Government in facing the issuance of Government Regulation Number 12 of 2019 so that human resource training needs to be carried out as a step in implementing it.

c. Human resources do not affect the readiness of the Padang City Government in facing the issuance of Government Regulation No. 12 of 2019 so that human resources are not ready to face these changes.

After conducting research and discussion of Factors Affecting Local Government Readiness in Facing the Application of Government Regulation Number 12 of 2019, researchers provide recommendations for the Padang City Government to carry out regular socialization of this rule and maintain the readiness indicated by human resources, commitment organization and infrastructure. These three factors are the most important references in carrying out preparatory activities regarding Government Regulation Number 12 of 2019. This shows that the activities to be carried out with these factors can run smoothly and well by taking into account the strategic steps of the City Government of Padang in preparing the implementation of the new rules. The limitations of this study include the following:

1) Taking samples at all OPD in Padang using random sampling. This is due to time constraints in the study so that for further research can use stratified sampling because it can be assessed based on the level of regional financial management in each existing OPD. 
2) Factors that influence the readiness of local governments in dealing with the application of Government Regulation Number 12 of 2019 have not been fully examined in this study. Thus, it is necessary to add other variables in further research such as leadership and communication styles so that the factors that influence the readiness of the government in dealing with the application of Government Regulation Number 12 of 2019 can be compared and fulfilled.

3) Researchers only use questionnaires by adding things that can be added as a substitute for interviews so that for further research there are interviews, conduct content analysis and conduct Focus Group Discussions (FGD) to employees or employees who are responsible for financial management so that the factors that influence it can be quantitative and qualitative.This literature review aims to identify and analyze the trends, datasets, methods and frameworks used in the topic of attribute independence assumption assumptions on NB between 2010 and 2018. Based on the inclusion and exclusion criteria designed, it shows 71 study studies of attribute independence assumptions on the published NB between January 2010 and December 2018 are investigated in this literature review have been conducted as a review of systematic literature. A systematic literature review is defined as the process of identifying, assessing, and interpreting all available research evidence in order to provide answers to specific research questions.

\section{References}

[1] M. Arya, "Laporan Keuangan Kota Padang Diganjar WTP.”, 2018.

[2] A. Jantong, "Faktor Determinan Kesiapan Persiapan Standar Akuntansi Pemerintahan Berbasis Akrual di Maggarai, Nusa Tenggara Timur", pp. 109-119, 2017.

[3] Sugiyono, Metode Penelitian Kuantitatif dan R\&D, 21st ed. Bandung: Alfabeta, 2014.

[4] I. B. G. B. Permana and I. D. N. Wiratmaja, "Pengaruh Sumber Daya Manusia, Komitmen Organisasi, Sistem Informasi pada Kesiapan Penerapan Laporan Keuangan Pemerintah Daerah Berbasis Akrual”, E-jurnal Akunt. Univ. Udayana, vol. 16, pp. 2260-2287, 2016.

[5] S. Arikunto, Penelitian Tindakan Kelas. Jakarta: Bumi Perkasa, 2015.

[6] D. Darmawan, Metode Penelitian Kuantitatif. Bandung: PT Remaja Posdakarya, 2014.

[7] Ridwan, Rumus dan Data Dalam Aplikasi Statistik. Bandung: Alfabeta, 2005.

[8] F. Yudiaatmaja, "Analisis Regresi dengan Menggunakan Aplikasi Komputer Statistik SPSS, Jakarta: PT Gramedia Pustaka Utama. M. Robnik-Siknja and I. Kononeko, 'Theoretical and empirical analysis of RelifF and RReliefF,' Mach Learn,” vol. 53, pp. 23-69, 2013.

[9] I. Ghozali, Aplikasi Analisis Multivariate dengan Program SPSS, 7th ed. Semarang: Badan Penerbit Universitas Diponegoro, 2013.

[10] Lobo, "Proses Pendapingan Artikel," 2008.

[11] C. Hood, "A Public Management For All Seasons?," Public Adm., vol. 6, no. 1, pp. 3-19, 1991.

[12] I. W. G. Y. D. Putra and D. Ariyanto, "Faktor-faktor yang Mempengaruhi Penerapan Standar Akuntansi Pemerintahan Berbasis Akrual," E-Journal Akunt. Univ. Udayana, vol. 1, pp. 14-32, 2015.

[13] E. Kristiawati, "Faktor-faktor yang Mempengaruhi Keberhasilan,” Akuntabilitas, vol. VIII, no. 3, pp. 171-190, 2015. 